\title{
The Influence of Psychological Intervention on the Mental State of Classical Wrestlers
}

\author{
Aebullah Demirli \\ Hitit University, Graduate School of Education \\ aebullah_demirli2552@ hotmail.com
}

\begin{abstract}
This study aims to examine the situational anxiety levels of wrestlers before and after competition using arrange of variables. A total of 39 elite athletes, 20 men and 19 women, who had previously won medals in World and European Championships, participated in the study during the Senior Turkish Championships in Adana in 2017. The study utilised the 'State-Trait Anxiety Inventory' which was introduced by Spielberger and colleagues in 1964, translated into Turkish and utilised by Oner and Le Compte (1983), and was applied to the wrestlers on the continuous-state anxiety scale. The Spss 21.00 package program was used for the data analysis, mainly the $T$ test, which determines the relationship between frequency distribution demographics, and the relationship between two independent variables and anxiety levels. In addition, the Anova Waryans test was used to determine the relationship between more than two variables and state anxiety levels. The difference between variables is determined based on the result p.0.05. The findings showed that the level of anxiety before the competition was higher than afterwards and there was found to be a significant difference between the genders and also wrestling styles. However, the results showed no significant difference when considering the variables of age, length of time competing at the chosen sport, level of education, parents' level of education, and situational anxiety levels before and after the competition. Based on the results, it is suggested that coaches educate themselves in the field of sports psychology and also consider working with experts in this field.
\end{abstract}

Keywords: Wrestling, Anxiety, Situational Anxiety, Sportsman

\section{Introduction}

Studies into how sports improve individuals and societies health, both psychologically and physiologically, go back a long way. In addition to being a product of discipline and culture, sports can be considered a scientific phenomenon. It is one of the biggest factors in the development of world peace and brotherhood (Tiryaki, 2000, 10). Human beings are complex because they have biological and psychological, as well as social competence. Sports offers a rich tool to help in understanding human psychology and personality types in social relations, this makes it an important determinant in understanding people. A number of studies have emphasized that when in the process of evaluating people's behaviour it is necessary to consider the determinants connected to the individuals mental state and their actions (İlbay, 2000, 2).

With sports becoming increasingly competitive, athletes must make extra efforts to prepare themselves psychologically and strengthen themselves physically in order to compete. It seems that performance is affected by many psychological factors, and not only physical strength will be enough to achieve success. One of these factors is anxiety. Although, anxiety can result in success for certain athletes (Morale and Tiryaki, 1990, 5).

Anxiety is a commonly felt and basic emotion in humans; occurring generally when faced with threatening situations (Akandere, 1997, 13), or when people perceive themselves to be in danger. This anxiety occurring in dangerous situations is called "situational anxiety" (Öner, 1983, 1). Before competition, athletes may experience situational anxiety, a mixture of excitement and fear. It may manifest in their mental, physiological, social and emotional responses. Often athletes feel stomach pain before a match, or have many negative thoughts, resulting in nervous behaviour. The effect of anxiety and stress on athletes in important matches is often easily visible (Erbas, 2000, 41).

Many sports psychologists describe stress and anxiety in a similar way: Activation in the sympathetic nervous system, but there are additional emotional and mental dimensions of stress (Konter, 1996, 45). Anxiety resulting from overworrying is one of the potential reasons for a decrease in athletic performance (Horris, 1984, 29). Anxiety can impair the athlete's decision-making process, alter their behaviour and hinder their abilities. A highly-anxious athlete may make a decision well outside of their normal character. In order to maximize performance in sports and eliminate physiological and psychological barriers, coaches and teachers need to do extensive research, improving their knowledge of the issue and being better able to support their athletes as a result (Tavacioglu, 1999, 40).

This study has aimed to demonstrate how wrestlers should be adequately prepared for competition, physically and psychologically, in order to get the highest level of performance in competitions. This should be done by examining the anxiety levels of wrestlers before and after competition while taking a range of variables into consideration.

\section{Methods}

\section{Study Design}

The examination of the wrestlers' conditional anxiety levels before and after the competition in terms of different variables will be analysed by pre-test and post-final test quantitative analysis. 


\section{Participants}

The subject pool was chosen from among athletes competing in the senior category of the Turkish Wrestling Championships. The study sample consists of 39 wrestlers; 19 men and 20 women, all having competed in the Turkish Wrestling Championships in Adana in 2017, and who had previously won medals in the World and European Championships.

\section{Data Collection}

Spielberger's "Continuous-Situational Anxiety Inventory" was used in the collection of research data together with the "Personal Information Form" created specifically by the researcher in order to collect relevant information about the demographic of the participants. Spielberger's State-Trait Anxiety Inventory scale was introduced by Spielberger and his colleagues in 1964 to determine levels of persistent and situation-related anxiety in humans. In 1983, Öner and Le Compte carried out the reliability and validity studies. The survey, which consists of 40 items, and is used for selfevaluation, consists of two parts; a 20-point "situational anxiety form" to determine what the athlete feels in the moment, and a 20-point "persistent anxiety form" used to find out how the athlete has been feeling over the last 7 days. A 20-point "situational anxiety form" was completed to determine the situational anxiety levels in wrestlers. The lowest score that can be obtained from the scale is 20 , and the highest score is 80 . The further up the scale the wrestler, the higher the level of situational anxiety.

\section{Personal Information Form}

The "Personal Information Form" prepared by the researcher and his advisor consists of 8 questions about the wrestler's demographic.

\section{Situational Anxiety Scale}

Spielberger's State-Trait Anxiety Inventory was introduced by Spielberger and his colleagues in 1964 to determine levels of persistent and situation-related anxiety in humans. In 1983, Öner and Le Compte carried out the studies of reliability and validity and translated the study into Turkish. This scale, which consists of 40 items and is one of the types of self-evaluation, consists of two parts: a 20-point "situational anxiety form" to determine what is felt at the moment and a 20-point "continuous anxiety form" created to reveal what has been felt in the last 7 days. On the Alpha reliability scale, a 4 pt. Likert type scale, participants initially scored between 83 and 87 , after test-retest reliability was done, results were between 71 and 86, substance reliability is between 34 and 72 (Öner and Le Compte 1998; Aydemir and Köroglu, 2000; Sahin et al., 2002).

\section{Data Analysis}

SPSS 21.00 for Windows program was used in the completion of data analysis. The scores obtained by the athletes from the two scales are scored in accordance with the directive. In order to expose differences between the groups in terms of situational anxiety, the Independent Samples $\mathrm{T}$ test was used to determine the relationship between the two variables and the situational level of anxiety, and the One-Way Anova test to determine the connection between more than two variables and the situational level of anxiety were used.

\section{Results}

This section will present the findings obtained from statistical analyses, and interpretations of the data.

Table 1: Sex of the wrestlers

\begin{tabular}{|c|c|c|c|}
\hline Gender & $\begin{array}{c}\text { Number } \\
(\mathrm{N})\end{array}$ & $\begin{array}{c}\text { Percentage } \\
(\%)\end{array}$ & $\begin{array}{c}\text { Total Percentage } \\
(\%)\end{array}$ \\
\hline Male & 19 & 48,7 & 48,7 \\
\hline Female & 20 & 51,3 & 100,0 \\
\hline Total & 39 & 100,0 & \\
\hline
\end{tabular}

Table 2: Wrestling styles

\begin{tabular}{|c|c|c|c|}
\hline Style & $\begin{array}{c}\text { Number } \\
(\mathrm{N})\end{array}$ & $\begin{array}{c}\text { Percentage } \\
(\%)\end{array}$ & $\begin{array}{c}\text { Total Percentage } \\
(\%)\end{array}$ \\
\hline Greco-Roman & 19 & 48,7 & 48,7 \\
\hline Freestyle & 20 & 51,3 & 100,0 \\
\hline Total & 39 & 100,0 & \\
\hline
\end{tabular}

Table 3: Status anxiety scale for male and female athletes, $T$ values of differences between pre-competition and postcompetition score averages, standard deviation and score averages

\begin{tabular}{|c|c|c|c|c|c|c|}
\hline $\begin{array}{c}\text { Situational } \\
\text { Anxiety Level }\end{array}$ & Gender & $\mathrm{N}$ & $\mathrm{X}$ & $\mathrm{Ss}$ & $\mathrm{T}$ & $\mathrm{P}$ \\
\hline $\begin{array}{c}\text { Pre-Competition } \\
\text { Anxiety Level }\end{array}$ & Male & 19 & 50,0526 & 7,38221 & 2,104 & \multirow{2}{*}{} \\
\cline { 2 - 8 } & Female & 20 & 44,3000 & 9,49848 & 2,118 & $041 *$ \\
\hline $\begin{array}{c}\text { Post-Competition } \\
\text { Anxiety Level }\end{array}$ & Male & 19 & 36,2105 & 6,01460 &,- 384 & \multirow{2}{*}{, 701} \\
\cline { 2 - 7 } & Female & 20 & 37,1000 & 8,20719 &,- 387 & \\
\hline
\end{tabular}

Table 3. shows differences in male and female scores under $\mathrm{P}$; there was a significant difference of 0.05 . higher in the situational anxiety levels of female wrestlers compared with male wrestlers.

However, when looking at the post-competition scores, there is no difference in the anxiety levels of male and female wrestlers.

Table 4: Pre-and post-competition score averages of GrecoRoman and Freestyle athletes from the situational anxiety scale. $\mathrm{T}$ values of differences between standard deviation and averages

\begin{tabular}{|c|c|c|c|c|c|c|}
\hline $\begin{array}{c}\text { Situational } \\
\text { Anxiety Level }\end{array}$ & Style & $\mathrm{N}$ & $\mathrm{X}$ & $\mathrm{Ss}$ & $\mathrm{T}$ & $\mathrm{P}$ \\
\hline $\begin{array}{c}\text { Pre-Competition } \\
\text { Anxiety Level }\end{array}$ & $\begin{array}{c}\text { Greco- } \\
\text { Roman }\end{array}$ & 19 & 50,0526 & 7,38221 & 2,104 & \multirow{2}{*}{,} \\
\cline { 2 - 7 } & Freestyle & 20 & 44,3000 & 9,49848 & 2,118 & $041 *$ \\
\hline $\begin{array}{c}\text { Post-Competition } \\
\text { Anxiety Level }\end{array}$ & $\begin{array}{c}\text { Greco- } \\
\text { Roman }\end{array}$ & 19 & 36,2105 & 6,01460 &,- 384 & \multirow{2}{*}{, 701} \\
\cline { 2 - 6 } & Freestyle & 20 & 37,1000 & 8,20719 &,- 387 & \\
\hline
\end{tabular}

Looking at Table 4, Greco-Roman and Freestyle wrestlers scores can be seen under P: On the pre-competition scores, based on the situational anxiety scale there is a significant difference of 0.05 , and the anxiety levels of Greco-Roman wrestlers are higher than that of freestyle wrestlers. In contrast, there was no significant difference in the average points after the competition. 
Table 5: Average points, standard deviations and average differences in results for wrestlers of different agesbefore and after the competition according to the situational anxiety scale

\begin{tabular}{|c|c|c|c|c|c|c|c|}
\hline Situational Anxiety Level & Age & $N$ & $X$ & Ss & $f$ & $P$ & Difference \\
\hline \multirow{4}{*}{ Pre-Competition Anxiety Level } & 20 years and under & 9 & 44,3333 & 9,48683 & \multirow{4}{*}{, 933} & \multirow{4}{*}{, 403} & \multirow{4}{*}{---- } \\
\hline & $21-23$ years old & 11 & 46,0909 & 10,98594 & & & \\
\hline & 24 years and older & 19 & 49,0000 & 7,23418 & & & \\
\hline & Total & 39 & 47,1026 & 8,91124 & & & \\
\hline \multirow{4}{*}{ Post-Competition Anxiety Level } & 20 years and under & 9 & 37,0000 & 8,86002 & \multirow{4}{*}{, 014} & \multirow{4}{*}{, 986} & \multirow{4}{*}{-----} \\
\hline & 21-23 years old & 11 & 36,4545 & 6,89005 & & & \\
\hline & 24 years and older & 19 & 36,6316 & 6,80858 & & & \\
\hline & Total & 39 & 36,6667 & 7,14266 & & & \\
\hline
\end{tabular}

Table 5. shows that athletes of different ages scored before and after the competition based on the situational anxiety scale under P; there was no significant difference at 0.05 .
However, it is one of the interesting results that increases the level of anxiety before the competition as the age increases.

Table 6: Score averages and standard deviations and the difference results between the averages according to the situational anxiety scale before and after the competition in wrestlers with different levels of experience

\begin{tabular}{|c|c|c|c|c|c|c|c|}
\hline Situational Anxiety Level & Time & $\mathrm{N}$ & $\mathrm{X}$ & Ss & $\mathrm{f}$ & $\mathrm{P}$ & Difference \\
\hline \multirow{4}{*}{$\begin{array}{l}\text { Pre-Competition Anxiety } \\
\text { Level }\end{array}$} & 11 years and under & 8 & 48,7500 & 6,29626 & \multirow{4}{*}{$\begin{array}{c}1, \\
929\end{array}$} & \multirow{4}{*}{, 160} & \multirow{4}{*}{---} \\
\hline & $12-14$ years & 12 & 43,0000 & 11,76281 & & & \\
\hline & 15 years and older & 19 & 49,0000 & 7,17248 & & & \\
\hline & Total & 39 & 47,1026 & 8,91124 & & & \\
\hline \multirow{4}{*}{$\begin{array}{l}\text { Post-Competition Anxiety } \\
\text { Level }\end{array}$} & 11 years and under & 8 & 40,1250 & 8,39111 & \multirow{4}{*}{$\begin{array}{c}1, \\
218\end{array}$} & \multirow{4}{*}{, 308} & \multirow{4}{*}{.--} \\
\hline & $12-14$ years & 12 & 35,4167 & \begin{tabular}{|l|}
7,53728 \\
\end{tabular} & & & \\
\hline & 15 years and older & 19 & 36,0000 & 6,22718 & & & \\
\hline & Total & 39 & 36,6667 & 7,14266 & & & \\
\hline
\end{tabular}

Table 6. shows results for wrestlers with different years of experience on the status anxiety scale under $\mathrm{P}$, including averages before and after the competition; It is of note that there is no significant difference in the level, only 0.05 .

Table 7: The $t$ value of the difference between the average and standard deviation values and the averages after the competition on the continuity and situational anxiety scale

\begin{tabular}{|c|c|c|c|c|c|}
\hline Situational Anxiety Level & $\mathrm{X}$ & $\mathrm{N}$ & Ss & $\mathrm{T}$ & $\mathrm{P}$ \\
\hline $\begin{array}{c}\text { Pre-Competition Anxiety } \\
\text { Level }\end{array}$ & 47,1026 & 39 & 8,91124 & & \\
\cline { 1 - 5 } $\begin{array}{c}\text { Post-Competition Anxiety } \\
\text { Level }\end{array}$ & 36,6667 & 39 & 7,14266 & 5, 477 & 000* \\
\hline
\end{tabular}

According to Table 7, the average score of wrestlers on the pre-competition and post-competition situational anxiety scale is P; There was a significant difference of 0.05 . It was seen that the wrestlers' instant anxiety levels before the competition were higher than afterwards.

\section{Discussion}

According to the results of the study comparing precompetition and post-competition anxiety levels for a total of 39 athletes; 20 men and 19 women who participated in the Turkish wrestling championships; When the anxiety levels of the wrestlers included in the study were examined, $\mathrm{P}$ taken from the averages of the pre-competition scores from the anxiety scale showed a significant difference of 0.05 . Instant anxiety levels in male athletes are generally found to be higher than that of female athletes. It was found that the instant anxiety levels of Greco-Roman athletes were higher than those of Freestyle wrestlers. It was also observed that there was no difference between the average points before and after the competition obtained from the instant anxiety scale of wrestlers with differences in age, difference in years of experience, or income levels. However, it is one notable result that the level of anxiety before the competition increases parallel to the increase in monthly income and age. It is among the results obtained that all athletes have higher levels of anxiety before the competition than after.

Looking at previous studies from Ozbay (2012), one in particular which supported this study, applied a continuous and situational anxiety scale to athletes on the national wrestling team, and while the results of male wrestlers before and after the competition showed significant differences in anxiety levels, it was noted that the difference between the anxiety levels of female wrestlers was not significant. One significant study in contradiction to this work from Çamliyer (1984), applied a situational anxiety scale to determine the level of stress experienced by the athletes resulting from their perception of the conditions causing stress in athletes, and it showed that they did not experience the pre-competition stress in a way that reached any significant level. Looking at this data, it is clear that the situational anxiety scale is highly sensitive in determining the effect of stress (since it is in line with other tests used to measure stress) and that athlete with a superior performance are not as strongly affected by anxiety. However, although all subjects were grouped as being selected from among performing athletes (boys-girls, young-adult, more or less experienced, those who did not see the competition as important), they experienced stress differently.

Erbaş and colleagues (2000), did a similar study with basketball players, showing the status anxiety scores that occur before competition. They examined a number of personal variables; biological age, years in training, length of time on the team, positions, injury, captaincy and intrateam relations, these seven personal variables had no significant impact on the situational anxiety score. However, 
in this study, the level of anxiety increases depending on age. This is attributed to the fact that basketball is a team sport and wrestling is an individual sport.

In another study that coincided with this one, Caglar (1997), looked at the effect of anxiety on the heart rate, beats per minute, they applied a continuous and situational anxiety scale to swimmers, and found significant differences between continuous and situational anxiety levels and continuous anxiety levels during training and precompetition periods, while finding significant differences between situational anxiety scores for the same periods.

According to Hacicaferoglu and Seçler (2015), who examined anxiety levels against a number of variables before the Folk's Games competition, found that there was a significant difference between a number of athletes dependant on age, gender and number of times competing in the folk games, in terms of feeling situational anxiety before the competition. Female athletes, aged between 20-22 and 17-19 and athletes who had participated in the folk games for less than a year, were found to have more immediate precompetition concerns than other athletes. In the study, it is thought that the lack of a significant difference between the age groups and anxiety levels of female athletes is due to the fact that the athletes in the working group are elite and experienced.

According to Dönmez (2013), which examined the continuous and situational anxiety levels of the athletes participating in inter-university basketball competitions held in Samsun Province, the gender of basketball players showed a significant difference in situational anxiety levels varying in number of years playing as a signed professional athlete. This difference was due to the fact that the scores of licensed players with above 8-11 and 12 years of experience were higher than those of licensed players of 0-3 years. In this study, it was observed that the age of the player does not affect the level of anxiety. It is thought that the aforementioned differences are due to one being a team sport and one an individual sport.

A study examining the strategies of footballers' coping mechanisms for stress, the factors affecting them and how they relate to these two found that stress levels, clubs, marital status, age, and level of education did not cause a significant difference in situational anxiety levels. (Tuncel, 2000).

In another study that coincided with this one, Yucel (2003) concluded that the constant and situational anxiety levels of athletes are not related to the age of the athlete. In another contradictory study, Engür (2002) found no significant difference in situational anxiety levels when comparing genders, this was based on a total of 279 athletes (224 males and 55 females) who participated in the "Impact of Success Motivation on Situational Anxiety Levels in Elite Athletes" study.

Finally, when preparing athletes for any competition, coaches should adapt their demeaner so as to distract the athletes from anxiety, and when possible, during training periods, competition periods, and especially right before competitions. To keep athletes away from stress and anxiety, they should place autogenic workouts in programs. Coaches should improve themselves in the field of sports psychology or it may be recommended to work with experts in the field.

\section{References}

[1] Çağlar, E., ve Koruç, Z. (1997). Müsabaka Kaygısının Dinlenik Kalp Atım Hızı Üzerine Etkisi, Hacettepe Ünv, Sosyal Bilimler Dergisi, s.18-32

[2] Çamliyer, H. (1984). Sporcularda Stres ve Stres Yaratan Faktörlere Göre Yaşanma Biçimleri, Doktora Tezi, Manisa, s.510

[3] Dönmez, K. H. (2013). "Samsun İlinde Yapilan Üniversitelerarası Basketbol Müsabakalarına Katılan Sporcuların Durumluk Kaygı Ve Sürekli Kaygı Düzeylerinin İncelenmesi. " TheJournal of AcademicSocialScienceStudies

[4] Erbaş, M. (2000). Türkiye Basketbol II. Ligindeki Oyuncuların Bazı Kişisel Değişkenlerinin Durumluk Kaygl Üzerine Etkileri ve Durumluk Kaygının Takım Içi ilişkilerine Etkisinin Araştırılması, Trakya Üniversitesi, Sosyal Bilimler Enstitüsü, Yüksek Lisans Tezi,. Edirne, s.38, 41, 70

[5] Erbaş, M. (2000). Türkiye Basketbol II. Ligindeki Oyuncuların Bazı Kişisel Değişkenlerinin Durumluk Kaygı Üzerine Etkileri ve Durumluk Kaygının Takım $\dot{I}_{c ̧ i}$ ilişkilerine Etkisinin Araştırılması, Trakya Üniversitesi, Sosyal Bilimler Enstitüsü, Yüksek Lisans Tezi,. Edirne, s.38, 41, 70

[6] Hacıcaferoğlu, S., Hacıcaferoğlu, B., ve Seçer, M. (2015). "Halk oyunları branşına katılan sporcuların yarışma öncesi kaygı düzeylerinin bazı değişkenler açısından incelenmesi. " International Journal of ScienceCultureandSport (IntJSCS) s.288-297.

[7] Horris, D. V. (1984). Sports Psychology. LeisurePress, Champaign Illinois, USA, s.29, 30, 34,

[8] İlbay, A., Bayram. (2000). Bireylerin Anksiyete, Empatik Beceri ve İlişkili, Özerklik Düzeylerinin Karşılaştırılması. Yüksek Lisans Tezi, Atatürk Üniversitesi Sosyal Bilimler Enstitüsü, Eğitim Bilimleri Anabilim Dal1, Erzurum, s.2

[9] Konter, E. (1996). Bir Lider Olarak Antrenör. Alfa Yayıncılık Ltd Şti.1. Basun, İstanbul, s.25

[10] Moral1, s. ve Tiryaki, Ş. (1990). Genç sporcularda yarışma performas kaygısı ve bu kaygı ile başa çıkma davranışlarının araştırılması, Hacettepe Üniversitesi Spor Bilimleri 1. Ulusal Sempozyumu, Ankara, s.5

[11] Öner, N. (1983). Le Compte, A; Süreksiz Durumluk / Sürekli Kaygl Envanteri El Kitabı. Boğaziçi Üniversitesi Yayınlar1, İstanbul, s.1-3

[12] Özbay, S. (2012). Büyükler Güreş Milli Takımında Yer Alan Sporcuların, Müsabaka Öncesi ve Sonrast Durumluk Kaygı Düzeylerinin Karşılaştırılması, Karamanoğlu Mehmet Bey Üniversitesi, Sosyal Bilimler Enstitüsü, Yüksek Lisans Tezi, Karaman

[13] Tavacıoğlu, L. (1999). Spor Psikolojisi. Sporsal Kuram Dizisi 23, Bağırgan Yayınevi, Ankara, s.39, 40, 42, 44

[14] Tiryaki, Ş. (2000). Tiryaki, Ş.; Spor Psikolojisi. Kavramlar, Kuramlar ve Uygulama. Eylül Kitap ve Yaymevi, Yaym No: 5, Üniversite Kitaplan Eğitim Dizisi: 1, Ankara, s.10 16 
[15] Tuncel Z, Yalçınkaya A. M, (2000). Futbolcuların Stres Düzeyleri ve Başa Çıkma Stratejileri

[16] Yücel, E. O. (2003). Taekwondocuların Durumluk ve Sürekli Kaygl Düzeyleri ve Müsabaka Başarllarına Etkisi, Gazi Üniversitesi, Sağlık Bilimleri Enstitüsü, Yüksek Lisans Tezi, Ankara, s.56 